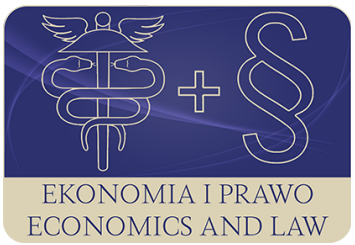

EKONOMIA I PRAWO. ECONOMICS AND LAW

Volume 17, Issue 2, June 2018

p-ISSN 1898-2255, e-ISSN 2392-1625

www.economicsandlaw.pl

ORIGINAL ARTICLE

received 13.06.2017; revised 16.03.2018; accepted 30.06.2018

Citation: Paszkowski, J. (2018). Methodological problems with evaluating change efficiency.

Ekonomia i Prawo. Ecomomics and Law, 17(2): 183-193.

doi:10.12775/EiP.2018.013.

\title{
Methodological problems with evaluating change efficiency
}

\author{
JERZY PASZKOWSKI \\ Bialystok University of Technology, Faculty of Engineering Management, Department of Managerial \\ Economics, ul. Ojca Tarasiuka 2, 16-001 Kleosin, Poland \\ $\square$ jerzy.paszkowski@pb.edu.pl
}

\begin{abstract}
Motivation: Changes result from a turbulent environment and internal situation of an organization. Rarely do changes happen spontaneously, usually they stem from decisions consciously shaped and taken by the management. Both the reasons as well as consequences of changes appear on multiple grounds and areas, often strongly interrelated. This leads to far-reaching consequences, mainly difficulties in practical operations as well as consequences for studies, analyses and related scientific generalizations and the conclusion-drawing process in both domains.

Aim: Purpose of this article is to present and make a critical analysis of the existing achievements in the area of evaluating change efficiency, and indicate opportunities and difficulties in formulating new, in particular synthetic, indicators of change efficiency. Methodology applied in this paper is deductive and based on collected data and their critical analysis.

Results: Managers need synthetic measures that are hard to develop. Various methods may be used in order to do it, starting from simple and complex point scales and ending up with methods applied in other sciences, e.g. the Geneva method or its variations applied to evaluate the standard of living and development. Still this requires the isolation of main analytical measures, their upper and lower thresholds, in subsequent change or process areas, and the application of statistical methods to calculate change status or effect. Such action requires longer change planning and preparation, readiness on the part of the managerial staff, and continuous monitoring with active participation of leaders and change managers.
\end{abstract}

Keywords: change; efficiency evaluation; analytical and synthetic measures of change evaluation JEL: All; B16; G34; D61 


\section{Introduction}

Change issues are observable both in regular operations of organizations as well as are widely described and analyzed in management and other social sciences. Changes result from a turbulent environment and internal situation of an organization. Rarely do changes happen spontaneously, usually they stem from decisions consciously shaped and taken by the management. Both the reasons as well as consequences of changes appear on multiple grounds and areas, often strongly interrelated. This leads to far-reaching consequences, mainly difficulties in practical operations as well as consequences for studies, analyses and related scientific generalizations and the conclusion-drawing process in both domains. In this respect, the evaluation of change efficiency in particular poses problems. However, it is not difficult to measure change efficiency in narrow and precisely defined areas (preferably isolated from others) and with clearly set objectives (preferably measureable). Measures may be based for instance on timing, financial means and related measurable indicators. There are multiple measures in every functional area of operations of a company. Nevertheless, comprehensive and thorough evaluation of change efficiency is hindered by interrelations between those areas and changes that make narrow, analytical measure inadequate. This gives rise to a problem with formulating synthetic measures that would allow more adequate evaluation not only of the course but also the effects of changes. Importance of the evaluation of change efficiency increases along with the extent and duration of given changes, which is particularly significant in the event of restructuring.

The purpose of this paper is to present and make a critical analysis of the existing achievements in the area of evaluating change efficiency, and indicate opportunities and difficulties in formulating new, in particular synthetic, indicators of change efficiency.

\section{Literature review}

Contemporary economic and social organizations function in environment which is becoming more and more complex and turbulent. Large number of interrelations, both internal as well as within the environment, especially in enterprises, causes process complications and economic dependencies. Changeability of resources and the need for flexible and quick reactions and decisions make it more difficult to draw conclusions and evaluate processes and phenomena subject to analysis. Also, we should add to this changes that occur in the functioning of an enterprise, either planned or not, which usually result from the necessity to adjust to the environmental changes.

Change is a common practice in every enterprise. As an area of research and analyses the issue of restructuring is present in many foreign and domestic publications (see: Anderson \& Ackerman (2010); Baugier \& Vuillod (1993); Bazerman \& Watkins (2006); Borowiecki (2011); Bridges (2008); Cannon \& 
McGee (2012); Clarke (1997); Jaki et al. (2011); Jick \& Peiperl (2010); Kanter (1983); Kotter (1996, 2014); Kotter \& Cohen (2007); Paszkowski (2009); Spector (2012); Taleb (2007); Ulrich et al. (2002)). In fact, all aspects of change have been classified and provided with definitions. There are many approaches to this topic and many conclusions may be drawn, obviously not necessarily unequivocal. Problems arise when it comes to practitioners implementing change-related analyses and requirements. Low efficiency of change and restructuring processes seem to confirm it (Mankins \& Rogers, 2011; Paszkowski, 2015, p. 128).

Change, change management (see: Borowiecki (2003, pp. 75, 78-79); Bratnicki (1997, p. 9); Czerska (1996, p. 12); Griffin (1996, p. 393); Hurry (1993, pp. 69-84); Koźmiński \& Piotrowski (2009, p. 507); Lachiewicz \& Zakrzewska-Bielawska (2005, p. 14); Masłyk-Musiał (1996, pp. 32-34); Muzyka et al. (1995, pp. 346-354); Robbins \& DeCenzo (2002, p. 323); Sapijaszka (1996, p. 27)), and restructuring processes (see: Borkowski et al. (2001, p. 116); Borowiecki \& Jaki (2002, pp. 360-367); Czermiński et al. (2001, pp. 457-458); Griffin (1996 p. 393); Koźmiński \& Obłój (1989, p. 287); Lachiewicz \& Zakrzewska-Bielawska (2005, pp. 28-29; 30); Mączyńska (2001, pp. 52-54); Nalepka (1999, p. 38); Nogalski et al. (1999, pp. 27-30); Penc (1998, pp. 278-279); Perechuda (1998, p. 9); Stabryła (1997, p. 132); Suszyński (2003, p. 128); Zarębska (2002, p. 83)), may be characterized by multiple features. Here are some of the most important ones:

- enterprises operate in unstable and risky conditions, sometimes even in chaos, where it is hard to make predictions about the future;

- changes inside an organization constitute a necessary reaction to a turbulent environment but may also result from anticipation and adopted strategy;

- the objective of any organization is to make it through, develop and create value;

- certain changes may be induced by enterprise stakeholders - their targets should also be considered and reconciled with efficiency of a given enterprise;

- greater significance is attached to change initiatives as in the end the role of a lead and change manager comes down to the role of a leader;

- continuity of changes is a must; however, it is advisable to introduce changes at intervals;

- each change should be carefully planned and each reaction should be predictable, but in practice the course of the entire process and reactions to it are often chaotic and emotional;

- permanent change is a method of continuous improvement of an organization and in consequence it is necessary to use sound management and 'dynamic stabilization', i.e. a process of constant but minor changes (Abrahamson, 2007, pp. 142-144), and to adjust the pace of changes and implement them at the right time;

- legal and ethical norms, including CSR principles should be observed in the change process, especially during restructuring; 
- consequences that may follow the clash of interests of various stakeholders need to be minimized, increased role of anticipation;

- change should be managed in a continuous way, only then may it lead to planned results;

- changes are always related to people; unlike in theory, in practice changes in the HR area require much more time;

- changes should be carefully planned and implemented in phases, e.g. Kotter's model (Kotter, 2014, pp. 26-27), and with the use of such methodologies as ADKAR or CHAMPS2.

Furthermore, changes constitute a natural process inherent in enterprise growth (see: Adizes (1988); Gościński (1989, pp. 150-151); Greiner (1972, pp. 37-46); Koźmiński \& Jemielniak (2008, pp. 453-456); Quinn \& Cameron (1983)).

\section{Methods}

The process of change measurement and evaluation is very complex. Basic measures focus on efficiency, perceived as a level of target realization, and effectiveness, which entails comparing effects with outlays. The problem is that in most change cases none of the above elements is precisely defined, which results from the aforementioned change features. The same applies to using soft and hard approaches, known as E and O Theories (Beer \& Nohria, 2000, p. 11), when evaluating changes and using only hard factors to make a general change evaluation (Sirkin et al., 2007, pp. 153-179). Those factors include: transformation duration, quality of actions performed by a project team (ability to implement change within a specific time-frame), involvement of the top management and employees and their additional effort understood as actions beyond regular duties required by a given change. Apart from the first one, it is hard to precisely measure the remaining factors. Yet, according to the authors, those factors make it possible to measure and predict the efficiency of designed changes.

Economic measures are often used in economics and management but in most cases they do not allow for an explicit evaluation of undertaken changes and restructuring processes. This phenomenon occurs both at the micro- as well as macroeconomic level. Applied measures include mainly efficiency (praxeological measure), economy, competitiveness (economic measures).

The financial standing of an enterprise may be evaluated in many ways with the use of various measures that, as a rule, assess a given state and show the past based on data and information included in financial and accounting documents. Also, attempts to measure enterprise value are made to evaluate enterprise value in the context of its intangible assets comprising mainly human capital, intellectual capital and other non-material assets (see: Leszczyński (2007); Orechwa-Maliszewska \& Paszkowski (2009)). Efficiency as an economic measure mainly refers to the analysis of revenues and costs. 
The main problem related to effectiveness evaluation lies in revenues and costs analysis. Monitoring the process of change implementation should concern both areas.

\section{Results}

Change implementation is always connected with employees because on the one hand employees and their work produce revenues and on the other generate costs. Revenue increase is one of the fundamental objectives of every enterprise. Evaluation measures adopted in this respect concern mainly the entire enterprise or its part directly responsible for sales. Sales volume is relatively easy to evaluate and thus the rate of sales increase may be related to the entire enterprise and/or to the evaluation of sales volume split by respective employees of the sales department. Innovations and changes related directly to the sales process may translate into results, provided that their costs are known. Nevertheless, the problem with evaluating revenue arises when work is immeasurable. So far there are no tools available that would permit explicit evaluation of revenue in such a situation. Methods used assume the calculation of average revenue (sales volume) per employee, which is perceived as simplified and outdated (Fitz-Enz, 2001, p. 43), while such tools as economic value added (EVA) of human capital or activity-based management (ABM) do not satisfy conditions for evaluating change effectiveness (see Kaplan \& Cooper (2002)). Moreover, tools used for measuring personnel controlling prove equally useless (see Sekuła (1999)). It appears that various scorecards are more helpful (see: Becker et al. (2002); Jabłoński \& Jabłoński (2011); Kaplan \& Norton (2001); Lewandowska \& Likierski (2005)), however, they do not include a direct reference to revenue generated by a single employee or a group of employees and aggregating partial rates is difficult.

Since change evaluation methods and measures discussed above prove poorly efficient, they may lead to different change evaluation by different stakeholders. The effectiveness of changes introduced in enterprises is assessed by many authors as poor or even very poor. According to P. Strebel (2007), who refers to reengineering: 'less than $50 \%$ of enterprises managed to implement changes successfully; moreover, others claim that this figure is only 20\%'. W. Ratyński (2002) or M. Tinnila (1995, p. 25; Kupczyk et al., 1998), draw similar conclusions. Furthermore, other authors (see: Kotler \& Schlezinger (2008); Krupa (2003); Mankins \& Rogers (2011)), and consulting companies ${ }^{1}$ have observed poor efficiency of change in other processes. This has been also confirmed by

${ }^{1}$ Artur Little's research carried out on 500 companies in the USA: only in one third of cases changes were successful, Business Process Reengineering: 70\% of companies failed to achieve assumed results; research conducted by McKinsey in Europe and in the USA: two thirds of companies that introduced quality programs and changes decided to renounce such strategy due to lack of financial benefits. 
research conducted in Poland by the Supreme Audit Office (NIK) ${ }^{2}$. As a consequence of incompetent implementation of changes, only $16 \%$ of companies are able to survive: this conclusion was reached based on results of research carried out amongst 1000 companies between 1962 and 1989 by R. Foster and S. Kaplan (2003).

At the macroeconomic scale the efficiency of restructuring processes in the industrial sector is evaluated with the use of the international competitiveness concept. Competitiveness may be analysed at the enterprise, sector or economy level. Various indicators are used, among others Balassa's Revealed Comparative Advantage Index. The course of changes indicates partial efficiency of restructuring processes applied to the national industry (Postuszny, 2011, pp. 49-61).

It is relatively easier to evaluate change progress by applying analytical measures based on indices that measure change and its progress in specific change areas. While there are many indices in every functional area of management, changes are related and lead to consequences in areas other than the primary one, which obviously complicates the evaluation process. Therefore, attention should be focused on work efficiency and output provided that planning and change process delivery is correct. Measures (indices) that can be applied include among others: work output being the value created by an employee, quantity and value of half-finished products used, stock, utilities, waste, savings, number of complaints, working time index and many others adopted from financial, HR or marketing analyses. Use of such measures involves making a comparison before, during and after the change introduction. That would enable ongoing monitoring and modification of actions in the event certain indices are found to be lower than initially assumed. This objective may be attained with the use of a scorecard that would cover the evaluation of change, work results and an employee's performance during change implementation. It should cover elements important from the point of view of the change as well as a grading scale.

Regardless of the above, evaluation systems applied to work positions and processes should be combined with a measurable evaluation of revenue and cost, for instance as an average per employee in an enterprise or its part (if possible). In this way drawing conclusions would be more correct.

Praxeological, systemic, process or benchmarking perspective may prove helpful in evaluating change efficiency (see: Kotler \& Caslione (2009, pp. 116121; 175-195); Rummler \& Brache (2000, pp. 43-57)).

2 See: report by the Polish Supreme Audit Office (NIK, 2012), regarding the pharmaceutical sector: negative assessment of the restructuring process, state-owned companies did not improve their competitiveness, the sector did not manage to create a strong group of companies that could compete with foreign entities, $3 / 4$ of subsidies were spent inefficiently; however, the privatization of $90 \%$ of Herbapol, 2/3 of Polfa and Cefarm was successful. NIK (2011) report regarding the defense sector: in 3 out of 9 companies, restructuring led to a lasting and efficient improvement. 
In terms of process efficiency, most research and analyses related to management above all highlight the significance of soft factors and the role of people management in the change process. This especially refers to organizational culture, leadership during the change process or motivation, overcoming resistance to change, information and communication system (see: Koźmiński \& Jemielniak (2008, p. 713); Steinmann \& Schreyogg (1992, p. 36)). Nevertheless, it is particularly difficult to design efficiency measures for this group of factors, same as in the case of evaluating actions and changes in the area of CSR (see: Aluchna (2011, pp. 73-76); Kemper \& Martin (2011, pp. 229-239); Paszkowski (2014, pp. 7-14); Porter \& Kramer (2011, pp. 36-57)).

\section{Conslusion}

Analysis of change management processes is very important both from the practical perspective as well as management sciences. Evaluation and measurement of process efficiency and effectiveness has a decisive impact on achieving success in management. Analytical measures, both quantitative as well as qualitative, used to evaluate effects, resources or future outcomes only in part allow for proper evaluation of the change course. When applying them it is important to:

- analyze the situation and precisely define final objectives (effects);

- design a time schedule and methodology of actions;

- select measures along with justification and boundary values;

- define connections and consequences for areas other than the main area of change;

- analyze application risks, especially the impact of a measurable evaluation on employees' behaviour;

- check whether it is possible to develop synthetic measures, verify their usability and value for organization.

It happens at times that little significance is attached to the above methodology which in consequence reduces change management efficiency. Managers need synthetic measures that are hard to develop. Various methods may be used in order to do it, starting from simple and complex point scales and ending up with methods applied in other sciences, e.g. the Geneva method or its variations applied to evaluate the standard of living and development. Still this requires the isolation of main analytical measures, their upper and lower thresholds, in subsequent change or process areas, and the application of statistical methods to calculate change status or effect. Such action requires longer change planning and preparation, readiness on the part of the managerial staff, and continuous monitoring with active participation of leaders and change managers. 


\section{References}

Abrahamson, E. (2007). Bezbolesne zarządzanie zmianą. In Harvard Business Review. Przywództwo w okresie zmian. Gliwice: Helion.

Adizes, I. (1988). Corporate lifecycles. New Jersey: Prentice-Hall.

Aluchna, M. (2011). Globalny kryzys finansowy jako test teorii społecznej odpowiedzialności biznesu. Przegląd Organizacji, 3.

Anderson, D., \& Ackerman, L. (2010). Beyond change management. San Francisco: Pfeiffer a Wiley Imprint.

Baugier, J.M., \& Vuillod, S. (1993). Strategie zmian w przedsiębiorstwie. Nowoczesna metoda. Warszawa: Poltex.

Bazerman, M.H., \& Watkins, M.D. (2006). Zagrożenia do przewidzenia. Jak wykrywać oznaki kryzysów w firmie i gospodarce. Gliwice: One Press.

Becker, B.E., Huslid, M.A., \& Ulrich, D. (2002). Karta wyników zarządzania zasobami ludzkimi. Kraków: Oficyna Ekonomiczna.

Beer, M., \& Nohria, N. (2000). Kombinacja twardej i łagodnej filozofii zmian. Zarządzanie na Świecie, 7.

Borkowski, J., Dyrda, M., Kanarski, L., \& Rokicki, B. (2001). Ludzie w organizacji. Warszawa: Dom Wydawniczy Elipsa.

Borowiecki, R. (2003). Zarządzanie restrukturyzacją procesów gospodarczych. Aspekt teoretyczno-praktyczny. Warszawa: Difin.

Borowiecki, R. (2011). Dylematy wspótczesnych przedsiębiorstw w procesie restrukturyzacji. Dywersyfikacja - integracja - rozwój. Kraków: AE w Krakowie.

Borowiecki, R., \& Jaki, A. (2002). Restrukturyzacja a procesy rozwoju i kreowania wartości przedsiębiorstw. Warszawa-Kraków: AE w Krakowie, TNOiK.

Bratnicki, M. (1997). Zarządzanie zmianami w przedsiębiorstwie. Katowice: AE w Katowicach.

Bridges, W. (2008). Zarządzanie zmianami. Jak maksymalnie skorzystać na procesach przejściowych. Kraków: UJ w Krakowie.

Cannon, J.A., \& McGee, R. (2012). Rozwój i zmiana organizacji. Warszawa: Wolters Kluwer Business.

Clarke, L. (1997). Zarządzanie zmiana. Warszawa: Gebether \& S-ka.

Czermiński, A., Czerska, M., Rutka, R., \& Apanowicz, J. (2001). Zarządzanie organizacjami. Toruń: TNOiK.

Czerska, M. (1996). Organizacja przedsiębiorstw. Metodologia zmian organizacyjnych. Gdańsk: Uniwersytet Gdański.

Fitz-Enz, J. (2001). Rentowność inwestycji w kapitat ludzki. Kraków: Dom Wydawniczy ABC.

Foster, R., \& Kaplan, S. (2003). Twórcza destrukcja. Warszawa: Galaktyka.

Gościński, J.W. (1989). Cykl życia organizacji. Warszawa: PWE.

Greiner, L.E. (1972). Evolution and revolution as organizations grow. Harvard Business Review, July-August.

Griffin, R.W. (1996). Podstawy zarządzania organizacjami. Warszawa:PWN. 
Hurry, D. (1993). Restructuring in the global economy: the consequences of strategic linkages between Japanese and U.S. firms. Strategic Management Journal, vol. 14(S1). doi:10.1002/smj.4250140907.

Jabłoński, A., \& Jabłoński, M. (2011). Strategiczna karta wyników. Teoria i praktyka. Warszawa: Difin.

Jaki, A., Kaczmarek, J., \& Rojek, T. (2011). Restrukturyzacja. Teoria i praktyka w obliczu nowych wyzwań. Kraków: Fundacja Uniwersytetu Ekonomicznego.

Jick, T.D., \& Peiperl, M. (2010). Managing change. Cases and concepts. Boston: McGraw-Hill.

Kanter, R.M. (1983). The change master. New York: Simon \&. Schuster.

Kaplan, R.S., \& Cooper, R. (2002). Zarządzanie kosztami i efektywnością. Kraków: Oficyna Ekonomiczna.

Kaplan, R.S., Norton, D.P. (2001). Strategiczna Karta Wyników. Jak przetożyć strategię na dziatanie. Warszawa: PWN.

Kemper, A., Martin, R.L. (2011). After the fall: the global financial crisis as a test of corporate social responsibility theories. European Management Review, 7(4). doi:10.1057/emr.2010.18.

Kotler, J.P., \& Caslione, J.A. (2009). Chaos. Warszawa: MT Biznes.

Kotler, J.P., \& Schlezinger, L. (2008). Wybór strategii przeprowadzania zmian. Harvard Business Review, 65-66.

Kotter, J.P. (1996). Jak przeprowadzić transformację firmy. Gliwice: One Press. Kotter, J.P. (2014). Accelerate. Boston: Harvard Business Review Press.

Kotter, J.P., \& Cohen, D.S. (2007). Sedno zmian. Autentyczne historie transformacji, które odmienity oblicza firm na catym świecie. Gliwice: One Press.

Koźmiński, A.K., \& Jemielniak, D. (2008). Zarządzanie od podstaw. Warszawa: PWN.

Koźmiński, A.K., \& Obłój, K. (1989). Zarys teorii równowagi organizacyjnej. Warszawa: PWE.

Koźmiński, A.K., \& Piotrowski, W. (2009). Zarządzanie. Teoria i praktyka. Warszawa: PWN.

Krupa, K. (2003). Ewolucja procesu zmian organizacyjnych. Wybrane poglądy i koncepcje. Łódź: Wydawnictwo Uniwersytetu Łódzkiego.

Kupczyk, A., Korolewska-Mróz, H., \& Czerwonka, M. (1998). Radykalne zmiany w firmie. Warszawa: Wydawnictwo Prawno-Ekonomiczne Infor.

Lachiewicz, S., \& Zakrzewska-Bielawska, A. (2005). Restrukturyzacja organizacji i zasobów kadrowych przedsiębiorstwa. Kraków: Oficyna Ekonomiczna.

Leszczyński, M. (2007). Inwestowanie w kapitat ludzki. Kielce: Akademia Świętokrzyska.

Lewandowska, A., \& Likierski, M. (2005). Pod presja czasu. Strategiczna Karta Wyników w praktyce. Warszawa: C.H. Beck.

Mączyńska, E. (2001). Restrukturyzacja przedsiębiorstw w procesie transformacji gospodarki polskiej. t. 1. Warszawa: DiG.

Mankins, M.C., \& Rogers, P. (2011). Dostosuj organizację do procesów decyzyjnych. Harvard Business Review, 98. 
Masłyk-Musial, E. (1996). Zarzadzanie zmianami w firmie. Warszawa: CIM.

Muzyka, D., De Koning, A., \& Churchill, N. (1995). On transformation and adaptation: building the entrepreneurial corporation. European Management Journal, 13(4). doi:10.1016/0263-2373(95)00029-k.

Nalepka, A. (1999). Restrukturyzacja przedsiębiorstwa. Zarys problematyki. Warszawa-Kraków: PWN.

NIK. (2011). Informacja o wynikach kontroli wspierania środkami publicznymi restrukturyzacji spótek przemystowego potencjału obronnego. Retrieved 16.03.2018 from https://www.nik.gov.pl.

NIK. (2012). Procesy prywatyzacji $w$ sektorze farmaceutycznym. Informacja o wynikach kontroli. Retrieved 16.03.2018 from https://www.nik.gov.pl.

Nogalski, B., Hałaczkiewicz, M., \& Witt, J. (1999). Restrukturyzacja procesowa w zarządzaniu matym i średnim przedsiębiorstwem. Bydgoszcz: TNOiK.

Orechwa-Maliszewska, \& E. Paszkowski, J. (2009). Przeptywy kapitatu intelektualnego i finansowego - aspekty lokalne i globalne. Białystok: WSFiZ w Białymstoku.

Paszkowski, J. (2009). Uwarunkowania i rezultaty zmian w przedsiębiorstwach. Białystok: WSFiZ w Białymstoku.

Paszkowski, J. (2014). Problems related to measuring the effectiveness of corporate social responsibility. Social Sciences, 85(3). doi:10.5755/j01. ss.85.3.8412.

Paszkowski, J. (2015). Evaluation of Change Effectiveness. In D. Niedziółka (Ed.), Considerations about the Economy. Warsaw: Warsaw School of Economics Press.

Penc, J. (1998). Zarządzanie dla przysztości. Warszawa: Profesjonalna Szkoła Biznesu.

Perechuda, K. (1998). Metody zarządzania przedsiębiorstwem. Wrocław: AE we Wrocławiu.

Porter, M.E., Kramer, M.R. (2011). Tworzenie wartości dla biznesu i społeczeństwa. Harvard Business Review Polska, 99.

Posłuszny, K. (2011). Konkurencyjność międzynarodowa jako miara skuteczności restrukturyzacji przemysłu. Ekonomia menedżerska, 9.

Quinn, R.E., \& Cameron, K. (1983). Organizational life cycles and shifting criteria of effectiveness: some preliminary evidence. Management Science, 29(1). doi:10.1287/mnsc.29.1.33.

Ratyński, W. (2002). Menedżerskie i organizatorskie metody zarządzania, Warszawa: Kodeks.

Robbins, S.P., \& DeCenzo, D.A. (2002). Podstawy zarządzania. Warszawa: PWE.

Rummler, G., \& Brache, A. (2000). Podnoszenie efektywności organizacji. Warszawa: PWE.

Sapijaszka, Z. (1996). Restrukturyzacja przedsiębiorstwa. Szanse i ograniczenia. Warszawa: PWN.

Sekuła, Z. (1999). Controlling personalny. Bydgoszcz: TNOiK. 
Sirkin, H., Keenan, P., Jackson, A. (2007). Twarde aspekty zarządzania zmianami. In Harvard Business Review. Przywództwo w okresie zmian. Gliwice: Helion.

Spector, B. (2012). Wprowadzanie zmiany $w$ organizacji. Teoria $w$ praktyce. Warszawa: PWN.

Stabryła, A. (1997). Podstawy zarządzania firmą: modele, metody, praktyka. Kraków: Oficyna Wydawnicza Antykwa.

Steinmann, H., \& Schreyogg, G. (1992). Zarzązanie. Podstawy kierowania przedsiębiorstwem. Koncepcje, funkcje, przykłady. Wrocław: Politechnika Wrocławska.

Strebel, P. (2007). Dlaczego pracownicy nie chcą zmian? In Harvard Business Review. Przywództwo w okresie zmian. Gliwice: Helion.

Suszyński, C. (2003). Restrukturyzacja, konsolidacja, globalizacja przedsiębiorstw. Warszawa: PWE.

Taleb, N.N. (2007). The black swan: the impact of the highly improbable. New York: Random House.

Tinnila, M. (1995). Strategic perspective to business process redesign. Management Decision, 33(3).

Ulrich, D., Kerr, S., \& Ashkenas, R. (2002). The GE work-out. New York: McGraw-Hill.

Zarębska, A. (2002). Zmiany organizacyjne w przedsiębiorstwie. Teoria i praktyka. Warszawa: Difin.

\section{Acknowledgements}

Author contributions: author has given an approval to the final version of the article.

Funding: this research was undertaken as part of the Management of Regional and Local Development project and was fully/jointly funded by a grant (S/WZ/4/2015).

Note: the results of this study were presented at 9th International Conference on Applied Economics Contemporary Issues in Economy (June 22-23, Toruń, Poland). 
